\title{
THE DIPLOMATIC CONFLICT BETWEEN SOUTH KOREA AND JAPAN: HAS THE CANDLELIGHT REVOLUTION BECOME THE CURSE OF LIBERAL DEMOCRACY?
}

\author{
Jaejun Sung ${ }^{1}$ \\ Hankuk University of Foreign Studies
}

\begin{abstract}
This article will analyze why Moon's administration have caused the current conflict with Japan and how the government has exploited the situation. In particular, this paper will examine the reason why Moon's administration denies the "Treaty on Basic Relations between Japan and the Republic of Korea" which was signed in 1965 and doggedly insists that Japan is responsible for this conflict. As the conclusion of this paper, we can see the issues occurring in South Korea regarding Japan can be attributable to the ideological basis.
\end{abstract}

Keywords: Candlelight Revolution, Jeogpyecheongsan, relationship between South Korea and Japan.

Título en Castellano: El conflicto diplomático entre Corea del Sur y Japón: ¿Se ha convertido la revolución de las velas en la maldición de la democracia liberal?

\section{Resumen}

Este artículo analiza por qué la administración de Moon ha causado el conflicto actual con Japón y cómo el gobierno ha explotado la situación. En particular, este documento examinará la razón por la que la administración Moon niega el "Tratado sobre las relaciones básicas entre Japón y la República de Corea", que se firmó en 1965 e insiste tenazmente en que Japón es responsable de este conflicto. Como conclusión de este artículo, podemos ver que las cuestiones que se plantean en Corea del Sur con respecto a Japón pueden atribuirse a un planteamiento ideológico.

Palabras Clave: La revolución de las velas, Jeogpyecheongsan, relaciones entre Corea del Sur y Japón

Copyright (C) UNISCI, 2019.

Las opiniones expresadas en estos artículos son propias de sus autores, y no reflejan necesariamente la opinión de UNISCI. The views expressed in these articles are those of the authors, and do not necessarily reflect the views of UNISCI.

\footnotetext{
${ }^{1}$ Jaejun Sung is Columnist, Hankuk University of Foreign Studies (HUFS)

E-mail :<jaejunsung@naver.com>

DOI: http://dx.doi.org/10.31439/UNISCI-77
} 


\section{Introduction}

Given the current economic and political status of South Korea, it is remarkable to consider that the country was founded in 1948, having a history of less than one hundred years. During this period, South Korea has undergone various periods of turbulence. Emerging from a period of colonization, it endured the Korean War, ideological conflicts, and has managed to achieve democratization. Throughout this time, South Korea has enjoyed unprecedented success from various aspects. This is not only due to its political system but also as a result of its geopolitical status. With four great powers surrounding South Korea, specifically China, Japan, Russia, and the United States, it has been able to benefit from its geopolitical location but at the same time assumed the responsibility for playing a major role in its international affairs. This diplomatic position, however, has come under pressure since the election of Moon Jae-in. Having placed more emphasis on ideological approaches to diplomatic issues, the Moon administration has seen its ties with Japan deteriorate. It is difficult to imagine that such an outcome could have emerged. Both countries are now locked in a trade war, which echoes the sentiments of President Donald Trump, who stated that a "trade war is good and easy to win."2

On July 1, 2019, Japan announced new trade restrictions that tightened controls on the export of three chemicals which are crucial for producing semiconductors in Korea. ${ }^{3}$ Japan based this action on the claim that South Korea was leaking sensitive information to North Korea. South Korea immediately challenged this action, but Japan stuck to its original position. Following this measure, Japan took matters further by removing South Korea from its "White List." " South Korea reacted by removing Japan from its own "White List." Though it is assumed that the damage to South Korea may be greater than that to $\mathrm{Japan}^{5}$ it is clear that both countries will suffer from this action.

How could both countries end up in this unprecedented crisis? Why is there no sign of any settlement between the two countries? To resolve this issue, we have to first find out why this conflict began in the first place. What was the driving force behind this conflict? Some people seek to understand this issue only in diplomatic terms. But there is nothing completely independent by itself, especially when concerned with politics. ${ }^{6}$ So, we have to ask ourselves whether this conflict actually emerged due to diplomatic reasons or rather, as Kissinger pointed out, to address the reasons underlying this conflict, ¿whether it should be considered in terms of its historical and cultural background? ${ }^{7}$

We can grasp a clue from the Shinzo Abe's remarks. He stated that "South Korea kept performing the act of destroying the relationship of trust by infringing on the 1965 Agreement" 8 By the infringement, he was referring to the verdict by South Korea's Supreme Court regarding

\footnotetext{
${ }^{2}$ Lee Wanghwi: “A trade war United States sees”, Sung Kyun China Brief, Vol. 6, no 4 (2018), pp. 152-157

${ }^{3}$ Under this new regulation, Japanese companies would need a license for each chemical when exporting to South Korea three at a time. These include fluorinated polyamides, photoresists, and hydrogen fluoride. This licensing process could take up to 90 days, which can have a serious impact on Korea's semiconductor industry.

${ }^{4}$ The list of nations which are exempted from additional export procedures for all products

${ }^{5}$ Kana Inagaki, Song Jung-a, Edward White: "Japan cuts S Korea from export 'white list' as trade tensions rise" Financial Times, 2 August 2019

${ }^{6}$ Aristotle (2019): Politics, Hash Books, p. 14376

${ }^{7}$ Henry Kissinger (2011): On China, London Penguin Books, pp. 536-542

${ }^{8}$ Lim Gyeonggu: “Abe once again blames South Korea, damage of trust between countries” Presian, 27 August 2019.
} 
compensation for the "Comfort Women". " The issue of the "Comfort Women" has long been a source of conflict between the two countries, which has been also entangled with the issue of forced labor. However, former President Park Geun-hye reached an agreement with Japan to manage this issue but under the Moon Jae-in administration the Supreme Court issued the verdict that Japanese companies should pay compensation for the forced labor.

For this action, Japan accused South Korea of destroying diplomatic trust. The question we must ask is whether South Korea unilaterally broke the agreement on the "Comfort Women" issue, neglecting legitimate procedure and if so, on what philosophically political ground was it possible. This article will show that the South Korean government destroyed the diplomatic agreement without legitimate procedural guarantee. The ground which made this possible can be explained in terms of the political identity that the Moon administration is pursuing. As President Moon explained, "this conflict is more about emotion, the historical grievance against Japan's colonization of South Korea." 10 This shows that South Korea's government is confronting these international issues not from a diplomatic approach but from an historicallybased ideology. This is the reason why this conflict is not just a diplomatic spat but is focused on colonialism and historical grievances. ${ }^{11}$

What is the political identity that the Moon administration is pursuing? Here, this identity is the way in which the diplomacy of South Korea's government has become one which is pursued in emotional terms not realistic ones. In fact, the answer to this question has already been provided by Moon himself. He has defined his government within the framework of the "Candlelight Revolution." What kind of political meaning does the Candlelight Revolution have for the Moon administration? The most recent incarnation of this movement emerged as part of the scandal surrounding former President Park Geun-hye who was impeached after influence-peddling crimes committed by her confidant Choi Soon-Sil. The suspicion suggested by the newspapers went public by this candlelight movement. ${ }^{12}$ The candlelight revolution for the Moon's administration in this regard has basically taken on the approach of Jeogpyecheongsan or the phasing out of past evils. ${ }^{13}$ It is no surprise that Moon's government defines itself as a candlelight government and the main priority for his government is to achive Jeogpyecheongsan.

There are different views regarding this revolution. Conservative newspapers see this as politically-biased incident instigated by left-wing newspapers. ${ }^{14}$ It is understandable that various people with different ideology may interpret the candlelight revolution in a range of ways. This diversity of opinion is the very spirit that South Korea's constitution guarantees. However, if this pursuit of diversity becomes the obstacle for pursuing individual freedom, it cannot be regarded as a liberal society. So, the function of a just state is to increase personal freedom under law, not to decrease it. ${ }^{15}$ In this regard, the question we must ask ourselves is under the Moon administration, whether this obstacle has emerged or not. This will be answered

\footnotetext{
${ }^{9}$ This refers to the women who were forced to be sex slaves for the Japanese army during World War II, some of whom are still alive today. Also see Economist, July 18, 2019, A trade dispute between Japan and South Korea has Trumpian echoes

10 "Opening Remarks by President Moon Jae-in at Emergency Cabinet Meeting", at https://english1.president.go.kr/BriefingSpeeches/Speeches/630

${ }^{11}$ Catherine Kim: "The escalating trade war between South Korea and Japan, explained”, Vox, 9 August 2019.

${ }^{12}$ Kim Jongseo: “Candle Light Protest \& Constitution Building”, Democratic Legal Studies, Vol. 63 (2017), pp. $77-137$.

${ }^{13}$ Jeogpye literally means the evil effects accumulated during long periods. Under the term of Jeogpye, President Moon sought to remove all trace of Koreans deemed as collaborators during Japanese rule and do away with deeprooted corruption.

${ }^{14}$ Byun Youngsu: "Discourse Analysis of Candlelight Rally Article", Han-Geul, Vol. 309 (2015), pp. 121-159

${ }^{15}$ Rusel Kirk, (2019): Concise Guide to Conservatism, Washington DC, Regnery Gateway.
} 
by examining the Candlelight revolution, which is part of the Moon administration's identity. With this, we can begin to grasp why South Korea's government has not approached this in diplomatic terms, why the previous agreement was so easily broken, and by conclusion, the current diplomatic conflict Korea faces.

To have a grasp of the characteristics of the Candlelight Revolution, a review of the existing studies will be conducted in section 1. For this, I confine it to the one that took place in 2016, which the Moon administration based its policies on. In section 2, based on the analysis of the Candlelight Revolution, I will trace the process of conflict between Japan and South Korea, by which we can see there is linkage between the Candlelight Revolution and the resulting international dispute. By conclusion, I will emphasize that the ideologically-based diplomatic approach that the Moon administration has pursued should be changed if it truly wishes to have a peaceful relationship with Japan.

\section{Candlelight Revolution}

Former President Park Geun-hye was impeached by corruption charges related to her confidant Choi Soon-Sil. The charges were made public by JTBC, a South Korean news broadcasting station. But the story JTBC reported was mostly speculation, for there was not so much evidence regarding this issue as the prosecution at the time reported. ${ }^{16}$ The accusation they suggested later proved argumentative, which led Choi Soonsil to file a suit against Son Seokhui, the chairman of JTBC. Until now it is not yet proven who is right, but the news report was enough to provoke demonstrations that came to be known as the Candlelight Revolution which called for the impeachment of President Park. ${ }^{17}$ With respect to the role of the Candlelight Revolution's calls for impeachment, progressive media outlets have considered it as democratic, even comparable with the 1987 June Democracy Movement (Hangyoreh, 2019). ${ }^{18}$

Reconsidering the impeachment of former President Park Geun-hye, the following question arises. How did the national assembly approve the impeachment that had not been determined by the law? On what perspective do we have to approach the Candlelight Revolution in relation to the constitution? South Korea is a liberal democracy, which is guaranteed by the Constitution. If there any malfunction existing in this system, it should be revised by the political leaders who are selected by the vote, following the procedure of law. ${ }^{19} \mathrm{With}$ this regard, it is hard to call something liberal democracy if someone or something outside the law tries to correct or change it. Then the question arises, was the Candlelight Revolution's movement supported by the law? Was the crowd who held the demonstrations selected by the voters? The answers to these questions are both no.

The Candlelight Revolution can be regarded as representative of the people, which means participation democracy. There is no denying that a democratic nation is founded by principle of the participation of the people so that participation democracy is to be the basis for democracy. But the arguments that a democratic nation is managed by the participation of people, that people's participation does not end at the vote, and that people themselves can step forward as the representative, do not mean people can actually get involved in the system without a vote. So, the Candlelight Revolution would fail, if it cannot enter into the system by the act of a vote. ${ }^{20}$

\footnotetext{
${ }^{16}$ Jung Hoyeong: "The possibility of manipulating the impeachment", NewDaily, 2 February 2019.

${ }^{17}$ Lee Jeongki: "A Study on College Students Perceptions of Freedomof Speech and the Determinants of Their Acts of Resistant Political Expression: With a focus on issues related to Choi Soon-sil (President Park Geun-hye) Scandal in 2016", Journal of Communication Science, Vol. 17, no 3 (2017), pp. 138-171.

${ }^{18}$ The public movement that forced the regime headed by Chun Doohwan to hold direct presidential elections.

${ }^{19}$ Milton Freedman (1990): Free to choose, San Duiego, Harcourt.

${ }^{20}$ Hong Seongtae: "The Candle Assembly and Democracy", Economy and Society (2008), pp. 10-39
} 
Thinking about the meaning of the Candlelight Revolution in the context of liberal democracy, the examination done by existing studies is questionable. What perspectives existing studies have on Candlelight Revolution? Kim Sanjoon suggests that this movement showed the great power by which people can progressively and enthusiastically challenge the existing democratic system when it is believed to be malfunctioning. ${ }^{21}$ Hong Seonggu suggests that Article 1 of the Constitution, provides the basis for the people to have the right to restore democracy in person when the representative system and democracy walks in the opposite side. ${ }^{22}$ Other existing studies argue that it was this movement which induced the National Assembly to pass the motion for impeachment and the Constitutional Court to grant it, which is the reason why it should be considered as the massive spurt of aspiration for democracy and "the Glorious Revolution". ${ }^{23}$ In these existing studies, the expressions "showed great power," "have the right to restore democracy," and "massive spurt of aspiration for democracy," and "Glorious Revolution" should not be interpreted as supporting the argument that people are able to get directly involved beyond the act of vote.

Why does liberal democracy limit the agent who can directly get involved in the system only to the ones selected by the vote? The reason for that is if we follow the participation democracy without any limitation by law, there is the possibility of being managed by the crowd. The problem for this is the tendency for the crowd, which is transforming the idea which has entered their brain into action, readily yielding to all suggestions, and having all the violence of feeling without the influence of reason. ${ }^{24}$ In this regard, if we let the crowd make their own choice in each instance, which must lead to the progressive destruction of freedom. ${ }^{25}$ This destruction of freedom is the reason why liberal democracy cannot be run on the expectation that all members will perform on the implied consent, but nation must require hierarchies in Fukuyama's terms, specifically trust. ${ }^{26}$ The nation which does not operate in this representative way cannot be called liberal democratic, which is rather to be called direct democracy, whose likely result is the corruption (Montesquieu ,1872, 126). ${ }^{27}$

If someone tries to deny this inseparable relationship between the representativeness and the liberal democracy, he should first deny the liberal democracy and the Constitution itself. In fact, there are studies which point out the problems of liberal democracy so that South Korea should progress not as representative democracy but as participation democracy by holding the Candlelight Revolution. Kim Daehwan argues that "as it is pointed out that the representative democracy which is adopted by the system of liberal democracy is away from the democratic representation, the limitation of liberal democracy is basically the result of the problem of the

\footnotetext{
${ }^{21}$ Kim Sangjun: "A System change from the division system to the two states system on the Korean Peninsula: for the huge Korean candlelight rallies to be a true revolution", Society and Theory, (2017), pp. 63-90.

${ }^{22}$ Hong Sunggu: "The Democratic Implications of the Candlelight Rallies for the Impeachment of Park, Geun-hye - Deliberative Democracy and Monitory Democracy”, Korea Media information, Vol. 89, (2018), pp. 149-178

${ }^{23}$ Kim Seontaek: "On the Forms of Government in the Perspective of Democratic Legitimation - Does the Candlelight Revolution require Constitutional Amendment for Changing the Form of Government?", Public law Journal, Vol. 18, no 4 (2017), pp. 85-109; Kim Sangjun: "A System change from the division system to the two states system on the Korean Peninsula : for the huge Korean candlelight rallies to be a true revolution", Society and Theory, (2017), pp. 63-90; Jung Seungan: "Focusing on the Political and Sociological Meaning of the Democratic Revolution of the Candlelight-Citizens democratic revolution", The Korean Journal of Law \& Society, Vol. 54, (2017), pp. 111-138.

${ }^{24}$ Gustave Le Bon (2019): The crowd: A study of the popular mind, Loki's Publishing, digireads,

${ }^{25}$ Friedrich Hayek (1998): Law, Legislation and Liberty, London, Routledge, at https://libsa.files.wordpress.com/2015/01/hayek-law-legislation-and-liberty.pdf

${ }^{26}$ Trust, in Fukuyama's term, is the expectation that arises within a community of regular, honest, and cooperative behavior, based on commonly shared norms, on the part of other members of that community; Fukuyama, F. (1995): Trust, New York, Free Press Paperbacks.

${ }^{27}$ M. de Secondat, Baron de Montesquieu (1899) : The spirit of the laws, New York, The Colonial Press.
} 
philosophy of liberalism". ${ }^{28}$ By the philosophical problem of liberalism, it means liberal philosophy denies the social aspect of human beings. In philosophical terms, human beings can be examined by the entity of individual and social beings, and on which aspect it should be stressed philosophers have different ideas. Then then question arises, is it reasonable if we deny the system of representative democracy based on this philosophically subjective interpretation?

Jung Byungkee argues that the identity of the people consisting of the Candlelight Revolution is the one who undergoes the period of contempt and hatred toward neoliberalism, having high interest at increasing the value of de-materialism and the social welfare and destroying the authoritarianism. ${ }^{29}$ The tendency to see all social issues attributable to liberalism and bureaucratic authoritarianism is not compatible with liberal democracy, rather it is the one supported by the left. ${ }^{30}$ The Constitution of South Korea states in Clause 119 that the Republic of Korea bases its order on economic freedom and creativity of the individuals and enterprises.

Denying the system of economic freedom is also echoed by the school of Frankfurt, which pursues the Marxist methodology in modern ways, suggesting that the freedom of enterprise spelled toil, insecurity, fear for the vast majority of the population, and authoritarianism. It also suggests that mechanization barred libido, which is the energy of life, from previous modes of realization. ${ }^{31}$ With the examination of the identity of people consisting of Candlelight Revolution, the question arises, can it be compatible with the Constitution that the crowd at the Candlelight Revolution is the basis for participation democracy?

There is a further study that defines liberal democracy in a questionable way. Hong Seongmin argues that the system of democracy should be based on the emotion people feel. He examines the reason for the Park's administration's failures based on people's emotion. He says that the incident of Sewol ferry disaster and the government mismanagement of the incident as the destruction of the democratic symbol of the government. ${ }^{32}$ He believes that the reason for this is that people have the feelings of inhumane and coldness toward the government. Is it constitutional to decide whether the nation is democratic or not based on the emotion people have? The linkage between the people's emotional disappointment and the failing of democracy is supported by Durkheim's theory, on which this study also builds. But thinking about Durkheim's view toward the individual, that ${ }^{33}$ strengthening the societal integration at the price of individualistic characteristic is for the democracy, ${ }^{34}$ whether his theory is compatible with liberal democracy is questionable.

With participation aspect taken apart from representative aspect of democracy, if we solely take the role of participation by the Candlelight Revolution as the means for liberal democracy, there remains the possibility that the law supporting the nation cannot be protected. The candlelight revolution going beyond the reign of the law has the possibility to become political means for specific interest groups. For example, Chung Chungrae, the former supreme political leader of the ruling party, Minjoo Party, tweeted that the verdict regarding the governor

\footnotetext{
${ }^{28}$ Kim Daehwan (1997): "Philosophy of participation and participation democracy”, in Participation democracy and Korean society, Changbi.

${ }^{29}$ Jung Byungkee: "The Consciousness of the Participants in the South-korean Candlelight Rally in 2016/2017 in Comparison to the European May 1968”, Journal of Korean Social Trends and Perspectives, (2017) pp. $261-291$.

${ }^{30}$ Fukuyama, Francis (2006): The end of history and the last man. New York, Simon and Schuster.

${ }^{31}$ Marcuse Herbert (1964): One-dimensional man, Boston, Beacon Press.

${ }^{32}$ Hong seongmin: "Emotional politics and Candle Revolution", Civil Society and NGO, Vol. 15, no 1 (2017), pp. $79-110$

${ }^{33}$ Durkheim wrote that the great upheavals in society, like great popular wars, sharpen collective feelings, stimulate the party spirit and the national one and, by concentrating activities toward a single end, achieve, at least for a time, a greater integration of society.

${ }^{34}$ Emile Durkheim (2006): On Suicide, London, Penguin classics.
} 
Kim Kyongsoo's engagement ${ }^{35}$ at the manipulation of a vote was for the revenge against President Moon. ${ }^{36}$ He tweeted that it is time to hold the Candlelight Revolution when Kim Kyongsoo was remanded in custody. ${ }^{37}$ People holding candlelight argued against the verdict not by the law, but by calling him Jeogpye. ${ }^{38}$

Even though the Candlelight Revolution has the merit of representing the spirit of participation democracy, it is also true that it is composed of emotional aspects away from regulation and law. So there always exists the danger that it can be employed by the anonymous public to circumvent the legal system. Before the Candlelight Revolution without reign of the law representing the specific interest group threatens the freedom of individual. This kind of candlelight is not the foundation of liberal democracy but the curse for it. That President Moon himself chooses the candlelight as the curse for liberal democracy is shown at his attempt to get rid of "liberal" from "liberal democracy" at the constitution. ${ }^{39}$ Who is Jeogpye President Moon refers to? ¿Can it be possible that Jeogpye he refers to is the one determined by the Candlelight Revolution not by the law? Under President Moon's government, this Candlelight Revolution has become the means to make anybody criminal. ${ }^{40}$

\section{Relations with Japan}

Since 1945, there have existed many historical disputes between South Korea and Japan. Underlying this conflict is the fact that throughout the first half of the twentieth century Japan occupied Korea as its colony. The memory of being occupied still remains a raw emotion among the Korean people as an issue that has not yet been solved. ${ }^{41}$ President Moon Jae-in has sought to define his administration based partly on this historical background. ${ }^{42}$ The result of this definition is represented as Jeogpyecheongsan. As Moon himself said, Jeogpyecheongsan is the main priority for his government. ${ }^{43}$

At first, it was limited to the field of history, but since 2016, it is no longer limited to historical issues but was extended to the policies of the previous conservative administrations, specifically Park Geun-hye and Lee Myung-bak. ${ }^{44}$ Jeogpyecheongsan seeks to define and eradicate evil is its objective so that it is based on the feeling of evil. It is quite worrying that a politically different stance is to be defined as evil based simply on the emotion. Such concerns were also echoed by Habermas. He pointed out that to avoid becoming emotional, ethnicity and the nation should be separated and the nation should be concretized by the constitution. ${ }^{45}$

Is there any chance that the feeling of hatred and law can stand side by side? The law requires pure spirit without any emotion but only within the law itself to make judgement.

\footnotetext{
${ }^{35}$ Kim Kyongsoo is suspected to have been engaged at the 2018 opinion rigging scandal.

${ }^{36}$ Jung Chung-Rae argued that for the reason that the former Chief Justice of the Supreme Court, Yang Seungtae, was arrested for the monopoly of jurisdiction, the judge, Sung Changho, who once worked under Yang SeungTae, sentenced Kim Kyungsoo guilty.

${ }^{37}$ Jeong Cheongrae (ssaribi): "Kim Gyeongsu is not guilty" February 2, 2019, 12:28 a.m. Tweet

${ }^{38}$ Kim Taehun: "Released Kim Kyungsoo, and Sung Changho before the trial”, Segyeilbo, 17 April, 2019

${ }^{39}$ Seo Jeonguk: "Democracy without freedom, what is the intention of Moon's administration?", Dailian, 4 May 2018.

${ }^{40}$ Kim Ilsoo: "Drain the Swamp and Swamp the Drain”, gosi-law, Vol. 62, no 12 (2017), pp. 2-4.

${ }^{41}$ Sang-ho Lee: "The Original Idea and Creative Thought of the Period of Japanese Rule on Korea Jeong In-bo's Shilsim(實心) Theory”, Studies in Confucianism (The Journal of Confucianism Research Institute), Vol. 14, (2006), pp. 143-175.

42 "A trade dispute between Japan and South Korea has Trumpian echoes", at https://www.economist.com/leaders/2019/07/18/a-trade-dispute-between-japan-and-south-korea-has-trumpianechoes

${ }^{43}$ Bae Junu: "The main priority for the government is 'Jeogpyecheongsan”, ChannelA, 19 July 2017

${ }^{44}$ Kang Seonghyeon: “The ghost of 'Sleaze' and 'Pro-North”, Hwanghae Review, Vol. 95 (2017), pp. 2-13.

${ }^{45}$ Habermas, Jügen (1998): The inclusion of the other, Cambridge, MIT Press.
} 
Hatred does not stand by the law and Jeogpyecheongsan does not either. That anybody holding the candlelight can make anybody a victim under the name of Jeogpye reminds us of the turmoil by the Red Guards during China's Cultural Revolution. ${ }^{46}$ Is there any relationship between Jeogpyecheongsan and the current diplomatic conflict between South Korea and Japan? If we look through the cause for this diplomatic conflict South Korea faces, we can see how Jeogpyecheongsan manifests itself.

The current Korea-Japan conflict was initiated when Japan excluded South Korea from its trade "whitelist." President Moon defined this action as economic retaliation against the Supreme Court's verdict regarding enforced labor during colonial period. ${ }^{47}$ Therefore the conflict between South Korea and Japan is not just a diplomatic issue but is rooted in this historical ideology. Much of the tensions have focused on the issue of whether the 1965 Normalization Treaty resolved the issue of compensation for the victims of forced labor during World War II. This tension came up again when South Korea's Supreme Court in 2018 ordered Japanese firms to compensate the victims of forced labor, thereby overturning the 1965 treaty. This verdict led Japan to take action on July 4, 2019 when it began restricting exports to South Korea. $^{48}$

The question then arises on how this issue of compensation remained unresolved? How does the issue persist even though there is an agreement between both countries? In the 1965 agreement, it is stated that any outstanding issues related to property, rights, or interests among nationals of both people are settled. ${ }^{49}$ Reflecting this agreement, on March 27, 2001, Japan's Osaka District court ruled against a Korean plaintiff who claimed compensation, an appeal was dismissed by the Osaka High Court on November 19, 2002 and was also rejected by Japan's Supreme Court on October 9, 2003.

Unlike Japan, the controversy regarding the compensation issue continued. As a result, on June 26, 2005, President Roh Moo-hyun chaired a committee to deal with the compensation issue which involved Moon Jae-in as the senior secretary for civil affairs. This committee concluded that "to the issue of comfort women, the legal responsibility of Japan's government still remains," but "to the issue of forced labor, it is to be considered settled by the 1965 Claims Settlement Agreement between Korea and Japan. South Korea's government admitted that the $\$ 300$ million it received is to be considered as the settlement for the compensation of forced labor" ${ }^{50}$ If this is the case, it is questionable how this issue came up again given that both countries admitted it had been settled.

In fact, the reason why even there existed a 1965 agreement, the controversy regarding compensation issue continued was that the conclusion south Korea made at 2005 assumed the

\footnotetext{
${ }^{46}$ A mass student-led paramilitary social movement guided by Mao Zedong, during the first phase of the Chinese Cultural Revolution; Kim Ilsoo: "Drain the Swamp and Swamp the Drain”, Gosi-law, Vol. 62, no 12 (2017), pp. $2-4$.

47 “Opening Remarks by President Moon Jae-in at Emergency Cabinet Meeting”, at https://english1.president.go.kr/BriefingSpeeches/Speeches/630

48 "A trade dispute between Japan and South Korea has Trumpian echoes", at

https://www.economist.com/leaders/2019/07/18/a-trade-dispute-between-japan-and-south-korea-has-trumpianechoes.

${ }^{49}$ Article II-1 is as follows, "the Contracting Parties confirm that [the] problem concerning property, rights and interests of the two Contracting Parties and their nationals (including juridical persons) and concerning claims between the Contracting Parties and their nationals, including those provided for in Article IV, paragraph $(a)$ of the Treaty of Peace with Japan signed at the city of San Francisco on September 8, 1951, is settled completely and finally."

50 "Press release holding a joint committee regarding following countermeasure for the document release for the Korean-Japanese Conference”, at http://www.koreanbar.or.kr/pages/japandata/view.asp?teamcode=\&category=\&page=1\&seq=7099\&types=1005 \&searchtype $=\&$ searchstr $=$
} 
shortage of legitimacy. The committee decision of June 26, 2005 included the phrase, "the compensation was insufficient at moral aspect." In using the phrase "moral aspect," the Roh administration left some room for South Korea to address this issue at a later date. ${ }^{51}$ In this sense of appealing to the emotional aspect and not relying upon the rules and principles of a diplomatic agreement, the lack of legitimacy was already evident at that time.

With this legal decision instituted by the Roh administration, the Seoul Central District Court ruled against the victims of forced labour on April 4, 2008 and Seoul High Court dismissed an appeal on July 16, 2009. So, ostensibly, until 2009, it seemed there was a consensus on the issue of compensation between Japan and South Korea. Yet behind the scenes there always remained the likelihood of the 1965 agreement being broken by suggesting it was "morally" insufficient.

This vulnerability of legitimacy was eventually broken when on May 24, 2012, Kim Neung-hwan, a justice of the Supreme Court, decided that the previous verdicts made by the Japanese Courts was against the Constitution and made reversed the previous decisions. $\mathrm{He}$ stated that "I made the verdict based on the feeling of founding a country." 52 Does the phrase "the feeling of founding a country" have legitimacy? What is the verdict like when it is made not from the law but from feeling? It cannot help but remind us that it is another example of the spirit of the Candlelight Revolution. As Kim Taegyu, chief prosecuting attorney, pointed out, if feeling was used for this argument, it can also be the counterevidence that shows its logic was unnatural or irrational. ${ }^{53}$

After this reversal, the third court decided that the claim was not settled. What was the logic behind this? Even though the 1965 agreement, the property, settled the issues completely and finally, the logic the third court employed was as follows, "unless the illegality by Japanese colonization was stated at all, the claim beyond the article IV (a), which is to say, the claim connected with the illegality of colonization does not seem to be included." 54 This can be rephrased as, because it was not literally stated "the illegality of colonization," the claim for the illegal act remains. Therefore only when Japan explicitly and directly confesses its sins, can both countries make an agreement. If the fact that there wasn't word of 'illegality' in the 1965 agreement can be the reason why the agreement itself is invalid, why in the first place did both countries make an agreement? Was it not because both sides implicitly agreed that the colonization was illegal? And why did the court, neglecting the fact that in the agreement there is the phrase "including those provided for in Article IV," seek to limit the claim as going beyond Article IV (a)? As Kim Taegyo argued, there is no point of having different interpretations regarding this phrase ${ }^{55}$ and there can be no doubt that the claim was settled by the 1965 agreement. For this reason, even though the issue of compensation should have been

\footnotetext{
${ }^{51}$ Kim Changrok: "Legal Structure of Righting the Wrongs of the Past between Korea and Japan”, Korean Journal of Legal History, Vol. 47 (2013), pp. 85-113.

${ }^{52}$ Park taein: "Verdict for the impressment shaking Korea and Japan...lead character, Kim Neunghwan, supporting role, impeachment", Joongangilbo, 15 August 2019.

53 "Current Chief Prosecuting Attorney argues against Supreme Court", at http://www.wikileakskr.org/news/articleView.html?idxno=61703

54 "Current Chief Prosecuting Attorney argues against Supreme Court”, at http://www.wikileakskr.org/news/articleView.html?idxno=61703

55 "Subject to the provisions of paragraph 2 no contention shall be made with respect to the measures on property, rights and interests of either Contracting Party and its nationals which are within the jurisdiction of the other Contracting Party on the date of the signing of the present Agreement, or with respect to any claims of either Contracting Party and its nationals against the other Contracting Party and its nationals arising from the causes which occurred on or before the said date."
} 
considered in a legitimate and systematic way, the Supreme Court made a verdict based on the matter of interpretation. ${ }^{56}$

After its reversal, the Seoul High Court decided on July 10, 2013 that Japanese industries pay compensation for the victims. After this verdict was made, President Park Geun-hye secured an agreement with Prime Minister Shinzo Abe, given the importance of economic and diplomatic relations with Japan. After this agreement, they both made a statement that all issues related to the "comfort women" are resolved "once and for all." South Korea received an apology and $\$ 9.5 \mathrm{~m}$ for the victims in exchange for promising that the Japan embassy has no responsibility for this issue and that South Korea will not use this issue as a diplomatic wedge again. But after President Park was impeached, President Moon dismissed this agreement under the name of Jeogpyecheongsan. The Supreme Court confirmed on October 30, 2018, that Japanese industries should compensate the victims. This is the point where Abe Shinzo called out the falling trust between the two sides and the very reason why Japan excluded South Korea from its "White List"

Keeping track of the history of the current dispute between South Korea and Japan, it is believed that this dispute began with the court's decision. There could be controversy at various levels as to whether the 1965 agreement was right or wrong. But the very spirit of liberal democracy is that the judicial branch should not consider the political meanings, rather it should remain focused on whether the interpretation of it infringed the general meaning of the law or not. Unfortunately, as Kim Taegyu said, the verdict made by the Supreme Court was employed as a means to incapacitate the general principles of the law. ${ }^{57}$ Even when there was an agreement between both countries, trying to deal with this issue in the sense of "the feeling of founding a country" and "at moral respect", it cannot help but be questioned whether this situation is the result of the Candlelight Revolution and Jeogpyecheongsan.

The reason for why this paper places responsibility for this conflict on President Moon lies with the fact that the ruling party of his government tried to use this diplomatic situation for political purposes. In the name of Jeogpyecheongsan, they have fermented the dispute with Japan, which is shown by a report made by the ruling party's think tank, the Korea Institute of Democracy. It clearly states that this dispute with Japan is going to be beneficial for the 2020 general election. As predicted, local governments encouraged this antagonism by installing banners labeled with "No Japan" slogans, banning Japanese products, and advocating a boycott campaign. ${ }^{58}$ Even the mayor of Busan, who belongs to the ruling party, sought to stop the business exchanges with Japan. And Cho Kuk, the senior secretary for civil affairs, posted the slogan of Jugchang-ga on his Facebook. ${ }^{59}$ President Moon also contributed to this during his participation of a ceremony which was for the economy but he mentioned about the history of Admiral Yi Sun-sin who fought against Japan during the Imjin War of $1592 .{ }^{60}$

Struck with the feeling of hatred, Jeogpyecheongsan, and the anti-legitimacy, distorted Candlelight Revolution, President Moon's administration did not approach this issue diplomatically. Thinking about South Korea's role surrounded by China, Russia, Japan and

\footnotetext{
${ }^{56}$ Lee Keungwan: "The Question of Individual Claims of the Korean Victims of Forced Labour Under the 1965 Claims Settlement Agreement between Korea and Japan from International Law Perspective: A Critique of the Korean Supreme Court's Judgments", Seoul Law Journal, Vol. 54, (2013), pp. 327 391

57 "Current Chief Prosecuting Attorney argues against Supreme Court", at http://www.wikileakskr.org/news/articleView.html?idxno=61703

${ }^{58}$ Kim Rayun: “A municipal ordinance against Japan”, Segye Ilbo, 19 August 2019.

${ }^{59}$ The "Song of Bamboo Spear" that was popular during the democracy movement against the military regime in the 1980s, which symbolized the antipathy against Japan.

${ }^{60}$ Yi Sun-Sin was a Korean naval commander, who fought against Japanese navy during the Imjin war in Joseon Dynasty.
} 
United States, there is the chance that this failure of diplomacy is not limited to the economy but also to global relationships. In fact, the more worrying aspect is what will happen beyond South Korea and Japan relationship, such as the deteriorating relationship between South Korea and United States. As a liberal democracy, South Korea has traditionally been a close ally of the United States, which has always been the case even during the period of previous progressive governments. For example, for all the political risks, former President Roh Moohyun agreed to dispatch Korean troops to Iraq and signed the Korea-U.S. FTA. Combined these led to him being regarded as "realistic pragmatist." ${ }^{61}$ Furthermore, former President Kim Daejung emphasized that the relationship between South Korea and Japan should not be stuck in the past, but be future-oriented. In this context, he founded a diplomatic foundation that helped to share each other's culture. ${ }^{62}$

This future oriented diplomacy followed by Kim Dae-jung and Roh Moo-hyun has not been adopted by President Moon. The phrase by The Blue House, "nation before alliance" 63 has been echoed by Donald Trump and evokes a sense of nationalism. Unstable relationship between South Korea, Japan and U.S. is resonated by the unprecedented threat from China and Russia. Just for 2019, there have been regular intrusions of South Korean airspace by China (15 times) and Russia (13times). This peaked on July 23, when a Russian surveillance aircraft twice flew into South Korea's Air Defence Identification Zone which led to warning shots being fired by South Korean fighter jets. ${ }^{64}$ The intriguing point is that Japan's government officially made a complaint regarding South Korea's action. It is believed that Japan raised the issue as a way to challenge South Korea over the Dokdo Island dispute reflecting the broader deterioration of relations. ${ }^{65}$ Furthermore, the U.S. reaction to this dispute is also worrying. Following the incident, the U.S. Department of Defense stated that "The U.S. strongly supports the South Korea's and Japan's action against China's and Russia's violation of airspace." This has been interpreted as trying to take neither side of South Korea and Japan by not stating which nation's 'airspace ${ }^{\text {'66 }}$

President Moon's emotionally based diplomatic approach has brought about a conflict with Japan, and has also further deteriorated the relationship with the United States. On August 22, 2019, the Moon administration reversed the General Security of Military Information Agreement (GSOMIA), an intelligence-sharing agreement with Japan, and on August 30, announced that it desired to expedite the return process of 26 U.S. military installations. ${ }^{67}$ Even though the Korean government sought to limit the issue of GSOMIA to the Korea-Japan relationship, it did not consider the stance of the United States and the impact it could have the alliance. ${ }^{68}$ In response, U.S. Secretary of State Mike Pompeo mentioned during his visit to Canada regarding this issue that, "We are disappointed to see the decision that the South Korea made about that information sharing agreement." 69

\section{Conclusion}

The current diplomatic conflict South Korea faces with Japan is on the verge of falling into a situation where no solution is left. Having paralyzed the bilateral agreement due to political

\footnotetext{
${ }^{61}$ Park Huiwon: "Roh Moohyun, Moon Jaein, similar but different, a man of principle” Nocutnews, 23 May 2019.

${ }^{62}$ Kang Byeonghwan: "Hwang Kyoahn reminded of Kim Daejung and Obuchi", Kyunghyang Shinmun, 18 August 2019.

${ }^{63}$ Park Sehwan: "Japan must be honest, national interest before alliance", Kukmin Ilbo, 30 August 2019.

${ }^{64}$ Moon Jewon: "Planning for direct line with Russia”, Asia Economy, 8 October 2019.

${ }^{65}$ Park Junu: "Japan trying for conflicting region”, Kukmin Ilbo, 27 Septempber 2019.

${ }^{66}$ Kim Jeongan: "U.S. supports for South Korea and Japan's action”, Channel A, 24 July 2019.

${ }^{67}$ Shin Nari: "Kang Kyungwha discusses returning U.S. army base”, Donga Ilbo, 18 September 2019.

${ }^{68}$ Oh Dongryong: "Ryu Jeseung talks about destroying GSOMIA", Chosun Ilbo, 30 September 2019.

${ }^{69}$ Michael R. Gordon, Andrew Jeong and Alastair Gale: "South Korea Ends Pact to Share Military Information", The Wall Street Journal, 22 August 2019.
} 
ideology, South Korea's government has destroyed its trust with Japan. Trust between nations is procured not by the feeling one has but by keeping promises. This is the point where South Korea is to blame for this conflict. Under President Moon, South Korea was buried under the idea that the public can do everything beyond the law. The spirit of the Candlelight Revolution under President Moon has succumbed to this approach. This can be the means for participation democracy, but expressed only within the system of law. If this is expressed beyond the law, it is a curse for liberal democracy disguised as participation democracy.

Under the presidency of Moon Jae-in, the Candlelight Revolution has become the symbol of weapon used against Jeogpye. The result of this distorted democracy spirit was represented as Jeogpyecheongsan by the Moon administration. As the Waseda University School of Political Science and Economics Professor Fukagawa Yukiko argued, the government of President Moon is subdued by activist thought, ${ }^{70}$ which is regarded as the extreme left movement based on the Marxist's ideology. Jeogpyecheongsan is also based on nationalism, spreading the idea that South Korea can do everything by itself. Before the political phrase "Nation before alliance" based on the nationalism, South Korea cannot expect strong alliance with U.S. and Japan.

Eric Hobsbawm predicted there would be little chance for obvious protectionism to appear. ${ }^{71}$ But in the circumstance where U.S. chose Donald Trump, the UK Boris Johnson, Italy 'five start movement', Russia Putin, China Xi jinping, and Japan Shinzo Abe, it is concerned whether Hobsbawm's prediction is wrong. In this situation, it might be worth questioning, ¿how should we deal with this situation within the system of liberal democracy?

In this issue, the decision made by president Moon to delay exiting GSOMIA is meaningful. What made president Moon make this decision? In fact, the approval rate for the president has dwindled for the issue of exiting GSOMIA and special measures agreement $(\mathrm{SMA})^{72}$. And it seemed the atmosphere of anti-japan has been dwindled. ${ }^{73}$ The linkage between approval rate and the diplomatic approach shows us that the voter's opinion can have influence on the president's policy direction. In this respect, the active expression of the public and its reflection on the direction of policy can be a potent tool for discouraging the atmosphere of protectionism. 'Market sovereignty' ${ }^{74}$ can function as a realistic alternative to the democracy. ${ }^{75}$

If President Moon really wants to resolve this situation, it would not be prudent for the government to not incite public antagonism toward Japan but rather it would be more effective to approach this problem as a diplomatic matter. In Japan, there has been signs of change. Secretary General of the Japan Liberal Democratic Party Nikai Toshihiro stated, "Japan should yield to South Korea what Japan should yield" and thereafter Samsung was selected as a 5G network solution provider in Japan. ${ }^{76}$ Now, it is time that President Moon took action. A rational approach is necessary, not the emotional one in this situation. How can this issue be dealt with rationally? The first part is to get past the spirit of the Candlelight Revolution, nationalism, and trivializing the law. Trust should be restored with Japan by sticking to the previous agreements.

\footnotetext{
${ }^{70}$ Jeong Cheolsun and Kim Hyeona: “Moon's government is controlled by activist ideology”, Munhwa Ilbo, 23 August 2019.

${ }^{71}$ Eric Hobsbawm (2008): Globalisation, Democracy and Terrorism, Abacus Software.

${ }^{72}$ Park Jimin: "For the issue of GSOMIA the approval rate of the president has dwindled to 46.9\%", Maeililbo, 25 November 2019.

${ }^{73}$ Lee youngho: “dwindled No Japan... Japanese Alcohol export increased”, Hankyung, 26 December 2019

${ }^{74}$ Market Sovereignty premises that it would be more efficient to continuously find out what people wants by market or market research than just count the vote through election.

${ }^{75}$ Eric Hobsbawm, (2008): Globalisation, Democracy and Terrorism, Abacus Software.

${ }^{76}$ Lee Misuk: "Resotre GSOMIA, and Alliance is alive", Munhwa Ilbo, 2 October 2019.
} 
With such trust restored, South Korea can actually take responsibility as the "middle-man" between Japan, North Korea and America, which President Moon has long envisioned. In order to achieve peaceful relations with North Korea, it is important to restore the relationship with Japan through rational eyes.

\section{Bibliography}

\section{Books}

Aristotle (2009) Politics, Oxford, Oxford University Press.

Durkheim, Emile (2006): On Suicide, London, Penguin classics.

Freedman, Milton (1990): Free to choose, San Duiego, Harcourt.

Habermas, Jügen (1998): The inclusion of the other, Cambridge, MIT Press.

Fukuyama, Francis (1995): Trust, New York, Free Press Paperbacks.

Fukuyama, Francis (2006): The end of history and the last man, New York, Simon and Schuster.

Hobsbawm, Eric (2008): Globalisation, Democracy and Terrorism, Abacus Software.

Hayek, Friedrich (1998): Law, Legislation and Liberty, London, Routledge, at

https://libsa.files.wordpress.com/2015/01/hayek-law-legislation-and-liberty.pdf

Kirk, Russel (2019): Concise Guide to Conservatism, Washington DC., Regnery Gateway.

Kissinger, Henry (2011): On China, London, Penguin Books.

Le Bon, Gustave (2019): The crowd: A study of the popular mind, Loki's Publishing, digireads.

Marcuse Herbert (1964): One-dimensional man, Boston, Beacon Press.

M. de Secondat, Baron de Montesquieu (1899) : The spirit of the laws, New York, The Colonial Press.

\section{Journal Articles}

Byun Youngsu: "Discourse Analysis of Candlelight Rally Article", Han-Geul, Vol. 309 (2015), pp. 121-159

Hong Seongtae: "The Candle Assembly and Democracy", Economy and Society, (2008), pp. 10-39

Hong Sunggu: "The Democratic Implications of the Candlelight Rallies for the Impeachment of Park, Geun-hye - Deliberative Democracy and Monitory Democracy", Korea Media information, Vol. 89 (2018), pp. 149-178

Hong Seongmin: "Emotional politics and Candle Revolution", Civil Society and NGO, Vol. 15, n 1 (2017), pp. 79-110

Jung Byungkee: "The Consciousness of the Participants in the South-korean Candlelight Rally in 2016/2017 in Comparison to the European May 1968”, Journal of Korean Social Trends and Perspectives, (2017) pp. 261-291.

Jung Seungan: "Focusing on the Political and Sociological Meaningof the Democratic Revolution of the Candlelight-Citizens democratic revolution", the Korean Journal of Law \& Society, Vol. 54 (2017), pp. 111-138. 
Kang Seonghyeon: "The ghost of 'Sleaze' and 'Pro-North", Hwanghae Review, Vol. 95 (2017), pp. 2-13.

Kim Ilsoo: "Drain the Swamp and Swamp the Drain", gosi-law, Vol. 62, no 12 (2017), pp. 2-4.

Kim Changrok: "Legal Structure of Righting the Wrongs of the Past between Korea and Japan", Korean Journal of Legal History, Vol. 47 (2013), pp. 85-113.

Kim Ilsoo: “Drain the Swamp and Swamp the Drain”, Gosi-law, Vol. 62, nº 12 (2017), pp. 24.

Kim Jongseo: "Candle Light Protest \& Constitution Building", Democratic Legal Studies, Vol. 63 (2017), pp. 77-137.

Kim Daehwan (1997): "Philosophy of participation and participation democracy", Participation democracy and Korean society, Changbi.

Kim Sangjun: "A System change from the division system to the two states system on the Korean Peninsula: for the huge Korean candlelight rallies to be a true revolution", Society and Theory, (2017), pp. 63-90.

Kim Seontaek: "On the Forms of Government in the Perspective of Democratic Legitimation Does the Candlelight Revolution require Constitutional Amendment for Changing the Form of Government?”, Public law Journal, Vol. 18, nº (2017), pp. 85-109

Lee Keungwan: "The Question of Individual Claims of the Korean Victims of Forced Labour Under the 1965 Claims Settlement Agreement between Korea and Japan from International Law Perspective: A Critique of the Korean Supreme Court's Judgments", Seoul Law Journal, Vol. 54 (2013), pp. 327 391

Lee Wanghwi: “A trade war United States sees”, Sung Kyun China Brief, Vol. 6, no 4 (2018), pp. 152-157

Lee Jeongki: “A Study on College Students Perceptions of Freedomof Speech and the Determinants of Their Acts of Resistant Political Expression: With a focus on issues related to Choi Soon-sil (President Park Geun-hye) Scandal in 2016", Journal of Communication Science, Vol. 17, no 3 (2017), pp. 138-171.

Sang-ho Lee: "The Original Idea and Creative Thought of the Period of Japanese Rule on Korea Jeong In-bo's Shilsim(實心) Theory”, Studies in Copnfucianism, The Journal of Confucianism Research Institute, Vol. 14 (2006), pp. 143-175.

\section{Press Articles}

Bae Junu: "the main priority for the government is 'Jeogpyecheongsan", ChannelA, 19 July 2017

Catherine Kim: “The escalating trade war between South Korea and Japan, explained", Vox, 9 Aug 2019

Kana Inagaki, Song Jung-a, Edward White: “Japan cuts S Korea from export 'white list' as trade tensions rise" Financial Times, 2 August 2019

Kim Taehun: "Released Kim Kyungsoo, and Sung Changho before the trial”, Segyeilbo, 17 April, 2019

Kim Rayun: “A municipal ordinance against Japan”, Segye Ilbo, 19 August 2019. r

Kang Byeonghwan: "Hwang Kyoahn reminded of Kim Daejung and Obuchi", Kyunghyang Shinmun, 18 August 2019. 
Kim Jeongan: “U.S. supports for South Korea and Japan’s action”, Channel A, 24 July 2019.

Lee Misuk: "Resotre GSOMIA, and Alliance is alive", Munhwa Ilbo, 2 October 2019.

Lim Gyeonggu: "Abe once again blames South Korea, damage of trust between countries” Presian, 27 August 2019.

Moon Jewon: "Planning for direct line with Russia”, Asia Economy, 8 October 2019.

Oh Dongryong: "Ryu Jeseung talks about destroying GSOMIA", Chosun Ilbo, 30 September 2019.

Park Jimin: "For the issue of GSOMIA the approval rate of the president has dwindled to 46.9\%", Maeililbo, 25 November 2019.

Park Tae-in: "Verdict for the impressment shaking Korea and Japan...lead character, Kim Neunghwan, supporting role, impeachment”, Joongangilbo, 15 August 2019.

Park Huiwon: "Roh Moohyun, Moon Jaein, similar but different, a man of principle" Nocutnews, 23 May 2019.

Park Sehwan: "Japan must be honest, national interest before alliance", Kukmin Ilbo, 30 August 2019.

Park Junu: “Japan trying for conflicting region”, Kukmin Ilbo, 27 Septempber 2019.

Seo Jeonguk: "Democracy without freedom, what is the intention of Moon's administration?", Dailian, 4 May 2018.

Shin Nari: "Kang Kyungwha discusses returning U.S. army base", Donga Ilbo, 18 September 2019.

Jeong Cheolsun and Kim Hyeona: "Moon's government is controlled by activist ideology", Munhwa Ilbo, 23 August 2019.

Jung Hoyeong: "the possibility of manipulating the impeachment", NewDaily, 2 February 2019.

Lee Youngho: "Dwindled No Japan... Japanese Alcohol export increased", Hankyung, 26 December 2019

\section{Oher On-Line Sources}

"A trade dispute between Japan and South Korea has Trumpian echoes", at https://www.economist.com/leaders/2019/07/18/a-trade-dispute-between-japan-and-south-korea-has-trumpianechoes

"Current Chief Prosecuting Attorney argues against Supreme Court", at http://www.wikileakskr.org/news/articleView.html?idxno=61703

"Opening Remarks by President Moon Jae-in at Emergency Cabinet Meeting”, at https://english1.president.go.kr/BriefingSpeeches/Speeches/630

"Press release holding a joint committee regarding following countermeasure for the document release for the Korean-Japanese Conference", at

http://www.koreanbar.or.kr/pages/japandata/view.asp?teamcode=\&category $=\&$ page $=1 \&$ seq $=$ 7099\&types $=1005 \&$ searchtype $=\&$ searchstr $=$

Jeong Cheongrae (ssaribi): “Kim Gyeongsu is not guilty”, 2 February 2019, 12:28 a.m. Tweet 